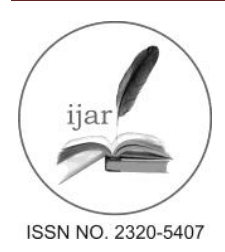

Journal homepage:http://www.journalijar.com
Journal DOI:10.21474/IJAR01

RESEARCH ARTICLE

\title{
SUITABILITY OF GROUND WATER FOR IRRIGATION PURPOSE IN DHARMAPURI DISTRICT.
}

\author{
P.Balamurugan, G.Sivakumar.
}

Assistant Professor, Department of Civil Engineering, Kongunadu College Of Engineering and Technology, Thottiyam.

\section{Manuscript Info \\ Manuscript History: \\ Received: 15 April 2016 \\ Final Accepted: 26 May 2016 \\ Published Online: June 2016 \\ Key words: \\ Groundwater, Chemical \\ Parameter,SAR,Percentage Sodium. \\ Abstract \\ The present study deals with the suitability of groundwater for irrigation purpose in study area. The samples are collected in 20 different locations in Dharampuridistrict. The following ten basic chemical parameters are investigated $\mathrm{pH}$, Total Alkalinity, Total Dissolved Solids, Hardness, Sulphates, Chloride, Fluoride, Calcium, Magnesium and Nitrate. The results are compares with IS 10500 to shows that the nature of water for irrigation purpose by using SAR Relationship, Percentage Sodium in groundwater.}

*Corresponding Author

\section{P.Balamurugan.}

Copy Right, IJAR, 2016,. All rights reserved.

\section{Introduction:-}

Water is an essential one for living organisms in the world. From the survey, a man can live without food for three to four days but no one can live without water for one day.(1) Groundwater is a main source of the water for living organisms in the world. It is used for domestic, industrial and irrigations purpose in nowadays. The quantity of the groundwater fully depends upon the recharged water, natural precipitations, inland surface water and sub-surface geochemical processes.(2) By naturally, the groundwater does not require any treatment for the use of domestic and irrigation purpose. Once the quality of groundwater is change to poor conditions, it is very difficult to come back into original position. Temporal changes in the different layers of soil mass, hydrologic and human activities may cause the nature of groundwater quality.(3,4) To examine the quality of ground water by determine the three different characteristics are Physical, Chemical and Biological. Temperature, Taste, Odour, Colour are physical characteristics of water. pH, Total Dissolved solids, Hardness, Alkalinity, Calcium, Magnesium, Chloride, Sulphate, Fluoride, electrical conductivity and heavy metals are the chemical characteristics of groundwater. Oxygen demand due to organic, inorganic and presence of bacteria, algae are the biological characteristics of groundwater.(4) The objective of the present work is to discuss the quality of water for irrigation purpose by determine the SAR Relationship, Percentage sodium in the study area. The SAR Relationship deals with the concentration of sodium, calcium, magnesium and Sodium Percentage is a major role in Irrigation purpose.

\section{Study area:-}

Dharmapuri district is a first district created in Tamilnaduafter independence in 1947. The historical name of the district is "Thakadoor". The geography form of the district is located between latitudes $11^{\circ} 47^{\prime}$ north and $12^{\circ} 33^{\prime}$ ' and longitude $77^{\circ} 02^{\prime}$ and $78^{\circ} 40^{\prime}$ East. It covers an area of $4497.77 \mathrm{~km}^{2}(3.46 \%$ of total area of Tamilnadu). It is bounded on the North by Krishnagiridistrict, on the East by Tiruvannamalai District and Villupuram District, on the South by Salem District and on the West by Karnataka State. Dharmapuri district is naturally very warm. During summer season, maximum temperature of the district is $38^{\circ} \mathrm{C}$ in April. During winter and rainy season, it has an $17^{\circ} \mathrm{C}$ in January. The average annual rainfall of district is $895.56 \mathrm{~mm}$. 


\section{Materials and methodology:-}

Groundwatersamples were collected from 20 locations from Dharmapuri district. The collected water samples were transferred into the plastic water bottle to carry out the chemical parameters of the water samples. $(5,9)$ The basic and major ions concentration of the water samples collected from the different locations by using standard procedures recommended by APHA-1994.(6,7) The results from the analysis were used to classify the water as suitable or unfit for drinking purpose and domestic purposes. Sodium Adsorption Ratio (SAR) is a measure of the suitability of water for use in agricultural irrigation, as determined by the concentrations of solids dissolved in the water.(8) If the value of SAR are found to be less than 10, it is excellent for irrigation, If the value of SAR is between 10 to 18 it is good for irrigation, the range between 18 to 26 is doubtful for irrigation and the if value exceeds 26 it is unfit for irrigation purpose.

$$
\mathrm{SAR}=\frac{\mathrm{Na}}{\sqrt[2]{(\mathrm{Ca}+\mathrm{Mg}) / 2}}
$$

The collected water samples are classified based on the percentage of sodium ions present in ground water. The percentage of sodium ions in water is determined by using the following formula.(10)

$$
\% \mathrm{Na}=\frac{\mathrm{Na}}{(\mathrm{Ca}+\mathrm{Mg}+\mathrm{Na}+\mathrm{K})} \times 100
$$

\section{Result and discussion:-}

Table 3 shows the chemical characteristics of groundwater samples collected from the study area.

\begin{tabular}{|c|c|c|c|c|c|c|c|}
\hline \multicolumn{2}{|r|}{ Sample station } & $\mathbf{C a}$ & Mg & $\mathbf{N a}$ & $\mathbf{K}$ & \multirow[t]{2}{*}{ SAR } & \multirow[t]{2}{*}{$\% \mathrm{Na}$} \\
\hline & & \multicolumn{4}{|c|}{$\mathrm{Mg} / \mathrm{l}$} & & \\
\hline S1 & Karimangalam & 72 & 102 & 129 & 59 & 13.8 & 35.6 \\
\hline $\mathrm{S} 2$ & Tellampatti & 42 & 78 & 159 & 3 & 20.5 & 56.4 \\
\hline S3 & Karagadapatti & 64 & 156 & 261 & 2 & 24.9 & 54 \\
\hline S4 & Oddapatti & 40 & 122 & 167 & 1 & 18.6 & 50.6 \\
\hline S5 & Periyampatti & 120 & 170 & 207 & 109 & 17.2 & 34.2 \\
\hline S6 & Adilam & 120 & 195 & 334 & 6 & 26.6 & 51 \\
\hline S7 & Attanur & 36 & 66 & 125 & 2 & 17.5 & 54.6 \\
\hline S8 & Yelangalapatti & 88 & 287 & 267 & 16 & 19.5 & 40.6 \\
\hline S9 & Belarahalli & 60 & 109 & 198 & 3 & 21.5 & 53.5 \\
\hline S10 & Chittirapatti & 44 & 77 & 213 & 2 & 27.4 & 63.4 \\
\hline S11 & Kavalpatti & 48 & 119 & 218 & 1 & 23.9 & 56.5 \\
\hline S12 & Dandakaranhalli & 40 & 100 & 231 & 7 & 27.6 & 61.1 \\
\hline S13 & Chikkarandahalli & 52 & 139 & 209 & 94 & 21.4 & 42.3 \\
\hline S14 & Timmampatti & 80 & 195 & 251 & 4 & 21.4 & 47.4 \\
\hline S15 & Kadamadai & 48 & 129 & 252 & 2 & 26.8 & 58.5 \\
\hline S16 & Mekalampatti & 48 & 95 & 222 & 2 & 26.3 & 60.5 \\
\hline S17 & Nallampatti & 32 & 29 & 76 & 0 & 13.8 & 55.5 \\
\hline S18 & Chinnappankottai & 40 & 60 & 124 & 4 & 17.5 & 54.4 \\
\hline S19 & Boppadi & 24 & 28 & 76 & 0 & 14.9 & 59.4 \\
\hline $\mathrm{S} 20$ & Palacode & 36 & 66 & 161 & 1 & 22.5 & 61 \\
\hline
\end{tabular}

Table 3:-Chemical characteristic of the groundwater sample in study area.

\section{Calcium:-}

Calcium is most essential for living organisms. Compared with other metals, the calcium ion and most calcium compounds have low toxicity. This is not surprising given the very high natural abundance of calcium compounds in the environment and in organisms.(11) High calcium intakes or high calcium absorption were previously thought to contribute to the development of kidney stones. A high calcium intake has been associated with a lower risk for kidney stones in more recent research.In study area, the concentration of calcium ion in groundwater samples range from 24-120 mg/L. Periyampatti and Adilam has a high level of calcium concentration in a study area. Boppadi has a low level of calcium concentration in study area. 


\section{Magnesium:-}

Magnesium is a one of the source of hardness in groundwater. When a magnesium combined with Sulphate, Chloride, Nitrate are required high degree of treatment for removal of permanent hardness in a water. The combination of the magnesium with bicarbonates and carbonates are temporary hardness in water.(12) It is easy to remove by simple methods of treatment. In a study area, the range of magnesium concentration is $28-287 \mathrm{mg} / \mathrm{L}$. Yelangalapatti has a maximum concentration of magnesium and exceeds the permissible limit recommended by WHO and IS 10500.Boppadi has a Minimum concentration of magnesium in a study area.

\section{Sodium:-}

The concentrations of sodium in groundwater are dependent on the local geological conditions and wastewater contamination. Saline intrusion, mineral deposits, sewage effluents, and salt used in road de-icing can all contribute significant quantities of sodium to water.(12) Domestic water softeners contribute to sodium in the drinking water by replacing the calcium and magnesium that make the water hard. These levels, though, are insignificant compared to the sodium ingested in the normal human diet. In study area, the concentration of sodium range from 76$334 \mathrm{mg} / \mathrm{L}$.Boppadi has a Minimum concentration of magnesium andAdilam has a high level of Sodium concentration in a study area.

\section{Potassium:-}

Potassium occurs in various minerals, from which it may be dissolved through weathering processes.Potassium is an dietary requirement for nearly any organism but a number of bacteria, because it plays an important role in nerve functions. Potassium plays a central role in plant growth, and it often limits it. Potassium from dead plant and animal material is often bound to clay minerals in soils, before it dissolves in water.(12) Consequently, it is readily taken up by plants again. Ploughing may disturb this natural process. Consequently, potassium fertilizers are often added to agricultural soils.In study area, the concentration of potassium range from 0-109 $\mathrm{mg} / \mathrm{L}$.Boppadi has a Minimumconcentration of potassiumandPeriyampatti has a high level of Sodium concentration in a study area.

\section{Sodium Absorption Ratio:-}

SAR is only one factor in determining the suitability of water for irrigation, in general, the higher the sodium adsorption ratio, the less suitable the water is for irrigation. Irrigation using water with high sodium adsorption ratio may require soil amendments to prevent long-term damage to the soil. The classification of groundwater samples in a study area for irrigation purpose with respect to SAR is presented in Table 1 . The $30 \%$ of the samples are "Good" for irrigation purpose and remaining $70 \%$ of the samples in a study area has doubtful and unfit for irrigation purpose due to nature of the soil, rock formation and disposal of domestic waste in a particular areas.

Table 1:- SAR Values for groundwater samples in the study area.

\begin{tabular}{|c|l|l|c|}
\hline S.No & \multicolumn{1}{|c|}{ SAR Values } & \multicolumn{1}{c|}{ Remarks on Quality } & No. of Samples \\
\hline 1 & $<10$ & Excellent & NIL \\
\hline 2 & 10 to 18 & Good & 7 \\
\hline 3 & 18 to 26 & Doubtful & 7 \\
\hline 4 & $>26$ & Unsuitable & 7 \\
\hline
\end{tabular}

\section{Percentage Sodium:-}

The classification of the water samples in a study area based on percentage sodium are given in the table 2 . From the 20 samples, $10 \%$ of the study area has good quality, $65 \%$ of the study area has permissible limit of the sodium values and remaining $25 \%$ of the study area has doubtful nature for irrigation purpose.

Table 2 Percentage Sodium values for groundwater samples in the study area

\begin{tabular}{|r|r|r|r|}
\hline S.No & \% Sodium & Remarks on Quality & No.of Samples \\
\hline 1 & $<20$ & Excellent & 0 \\
\hline 2 & 20 to 40 & Good & 2 \\
\hline 3 & 40 to 60 & Permissible & 13 \\
\hline 4 & 60 to 80 & Doubtful & 5 \\
\hline 5 & $>80$ & Unsuitable & 0 \\
\hline
\end{tabular}




\section{Conclusion:-}

Chemical characteristic of groundwater is analyzed in the present study. Around 20 samples were collected from the different locations in a Dharmapuri district and compare the result with WHO and IS 10500 for irrigation purpose. By using the SAR relationship and Percentage of sodium are the main factors to classify the samples. From the analyzed results and interpretation of results, Boppadi, Yelangalapatti and Periyampatti has a high level concentration of the chemicals parameters of water due to nature of the soil, rock formation, disposal of waste from industries and domestic areas from the Dharmapuri district. Finally the $60 \%$ of the samples need some treatment for the use of irrigation purpose in the study area.

\section{Reference:-}

1. J.ColinsJohnny and M.C.Sashikkumar, “ Groundwater Quality Assessment in Dindigul District, Tamilnadu using GIS” NEPT, Vol 13, 49-56,2014.

2. I.N Karthika, M.S.Dheenadayalan, "Study of Groundwater Quality at Selected Location in DindigulDistrict,India" JACS, Vol 1, 2015.

3. N.C.Mondal,V.P.Singh "Need of Groundwater Management in Tannery Belt",NGRI Hyderabad

4. Sharma, J.D., P. Sharma, P. Jain and D. Sohu, 2005. Chemical Analysis of Drinking Water of Sanganer Tehsil, Jaipur District, International Journal of Environmental Science and Technology,

5. 2(4): 373-379. [5]. Fakhrealam - Arab J Geosci (2014)"Evaluation of Hydrogeochemical Parameter of groundwater for suitability of domestic and irrigational purpose, a case study from central ganga plain, India"

6. Naseem Us Saba-Rashid Umar-Arina Khan - Arab J Geosci (2015) "Evaluation of chemical and microbial quality of ground water of Moradabad city,India"

7. N.C. Mondal,V.K.Saxena,V.S.Singh - Environ Geol (2005) 149-157 “Assessment of Groundwater Pollution due to Tannery Industries In and Around Dindigul,Tamilnadu,India”

8. T.R.Kalaivani,M.S.Dheenadayalan - IRJES Vol-2,66-73 Dec-2013 “Seasonal Fluctuation of Heavy Metal Pollution in Surface Water

9. Curhan, GC; Willett, WC; Rimm, EB; Stampfer, MJ (1993). "A prospective study of dietary calcium and other nutrients and the risk of symptomatic kidney stones" (PDF). The New England Journal of Medicine.

10. Bihl G; Meyers A. (2001). "Recurrent renal stone disease-advances in pathogenesis and clinical management"

11. Hall WD; Pettinger M; Oberman A (2001). "Risk factors for kidney stones in older women in the Southern United States". Am J Med Sci322 (1): 12-18.

12. T.V.Ramachandra,H.A.Bharath"Understanding urban sprawl dynamics of Gulbarga-tier II city in Karnataka through spatio-temporal data and spatial metrics" IJGG, Vol 3,2013. 